\title{
Compelling Experts To Testify: A Proposal
}

There is no consensus among American courts as to when experts should be compelled to testify. ${ }^{1}$ The various rules on compulsion of expert testimony have developed primarily in cases in which the experts were already involved in the litigation, either as observers of the underlying events or as expert witnesses employed by one of the parties. More recent cases, however, have involved experts whose connection to the litigation was more tenuous. ${ }^{2}$ When a party is convinced that a particular expert's testimony will be favorable, the litigant may seek that testimony without regard to the expert's willingness to testify. For example, a litigant might subpoena an unwilling expert who has previously expressed his opinion on a trial issue in a publication ${ }^{3}$ or in a prior trial of a related matter. ${ }^{4} \mathrm{~A}$ party may also wish to compel an expert to testify to his factual observations, in which case the expert's opinion would be irrelevant.5 The variety of possible situations raises the question of whether trial courts at present are allowed sufficient flexibility to effect a fair compromise between the competing interests involved when a litigant seeks to compel an unwilling expert to testify.

The purpose of this comment is to analyze these competing

1 Cases concerning compulsion of expert testimony are collected in Annot., 77 A.L.R.2d 1182 (1961). Several articles have discussed the approaches used by various states. The articles have focused primarily on expert witness fees. See, e.g., Hall, Extra Compensation for Expert Witnesses, 2 J. For. ScI. 81 (1957); Porterfield, The Right to Subpoena Expert Testimony and the Fees to Be Paid Therefor, 5 Hastings L.J. 50 (1953); Bomar, The Compensation of Expert Witnesses, 2 LaW \& ConTEMP. Prob. 510 (1935); Comment, Expert Witness Fees, 43 J. CRIM. L.C. \& P.S. 777 (1953); Comment, Requiring Experts to Testify in Maine, 20 U. ME. L. Rev. 297 (1968).

2 See, e.g., Kaufman v. Edelstein, 539 F.2d 811, 820 (2d Cir. 1976); Karp v. Cooley, 349 F. Supp. 827 (S.D. Tex. 1972), aff'd, 493 F.2d 408 (5th Cir.), cert. denied, 419 U.S. 845 (1974); Commonwealth v. Vitello, _ Mass. __, 327 N.E.2d 819 (Mass. 1975); In re Estate of Rothko, 80 Misc. 2d 140, 362 N.Y.S.2d 673 (Sup. Ct. 1974).

3 For example, in In re Westinghouse Elec. Corp. Uranium Contract Litigation, M.D.L. No. 235 (E.D. Va.), the plaintiffs subpoenaed for deposition an economist who had written a law review article concerning the case that reached a conclusion favorable to the plaintiffs (notice of deposition filed, No. 77-EBD, D. Mass. Feb. 28, 1977). On May 9, 1977, the defendants obtained a subpoena duces tecum for the expert's working papers and the magistrate ruled that the economist could be deposed, but the parties withdrew their subpoenas before the district court decided the appeal (telephone interview with Clerk of District Court of Massachusetts).

- See, e.g., Carter-Wallace, Inc. v. Otte, 474 F.2d 529, 536 (2d Cir. 1972), cert. denied, 412 U.S. 929 (1973).

${ }^{3}$ See, e.g., Rizzuto v. Employers Liab. Assurance Corp., 152 So. 2d 857, $858-59$ (La. Ct. of App. 1963) (doctor testified to the extent of plaintiff's injuries without giving medical opinion). 
interests in an effort to formulate an approach that achieves a workable compromise between the demands of litigants and experts. The comment first discusses the special characteristics of expert testimony and argues that these characteristics warrant treating experts differently than other witnesses. After describing and criticizing the procedures currently used by the courts, the comment proposes an alternative that more adequately accommodates the competing interests. Finally, the comment outlines a suggested approach to the analogous problem of compelling experts for depositions that is consistent with the suggested system for compulsion of trial testimony.

\section{The Special Case of the Expert Witness}

The duty of witnesses to testify is a sacrifice due from every member of a community. ${ }^{6}$ Expert testimony, however, differs from ordinary testimony in two important respects. ${ }^{7}$ First, the expert is asked not only to report his perceptions of events he has observed - as is the ordinary witness-but also to employ the resources he has invested in his training in order to draw inferences and form conclusions. The expert possesses a kind of equity in the substance of his testimony that is created by his investment of resources. ${ }^{8}$

- 8 J. WIGMORE, EvidENCE $\S 2192$, at 72 (McNaughton rev. 1961) [hereinafter cited as 8 WIGMORE].

7 Every witness is an "expert" in the matter to which he is called to testify. Nevertheless, two broad groupings of kinds of subjects exist: those "as to which a sufficient experience is possessed by every person of ordinary fortunes in life," and those "as to which it is only by means of some special and peculiar experience, more than is the common possession, that a person becomes competent to acquire knowledge." 2 J. WIGMORE, EVIDENCE § 555, at 633-34; id. § 556, at 635 (3d ed. 1940) [hereinafter cited as 2 WIGMORE]. In this latter category of expert testimony, witnesses may give opinion as well as fact testimony if the opinion will aid the trier of fact. See C. McCormick, Evidence § 13, at 29-30 (2d ed. 1972) [hereinafter cited as MCCormick].

"It has often been argued that experts have property rights in their expert knowledge because of their investment in their training, and that this property right cannot constitutionally be taken without providing adequate compensation. This argument was accepted in a few early cases. See, e.g., Cheatham Elec. Switching Device Co. v. Transit Dev. Co., 261 F. 792 (2d Cir. 1919); United States v. Howe, 26 F. Cas. 394 (W.D. Ark. 1881) (No. 15,404a); Pennsylvania Co. for Ins. v. City of Philadelphia, 262 Pa. 439, 105 A. 630 (1918); United States ex rel. Rock Creek Park v. Cooper, 21 D.C. (Tuck \& Cl.) 491, 497 (1893); see Friedenthal, Discovery and Use of an Adverse Party's Expert Information, 14 Stan. L. REv. 455, 479-81 (1962). The property concept has also been invoked in some recent cases. See, e.g., Petitioner's Brief for Certiorari at 26, Grinnell Corp. v. Hackett, 70 F.R.D. 326 (D.R.I. 1976), mandamus denied, No. 76-1346 (1st Cir. Aug. 17, 1976), cert. denied, 97 S. Ct. 1325 (1977).

Most cases have either rejected or ignored the property argument and have assumed the power to compel experts to testify. See, e.g., United States v. IBM Corp., 406 F. Supp. 175, 176-77 (S.D.N.Y. 1975); United States v. IBM Corp., 406 F. Supp. 178 (S.D.N.Y. 1976). The rationale usually advanced for rejecting the property argument is that the court is not asking the expert to render professional services but is only requiring testimony as it does of all 
Second, expert testimony, unlike ordinary testimony, is often replaceable. In the case of ordinary witnesses the litigant generally wants the witness to testify about his perceptions of events the litigant deems important to his case. When a litigant seeks testimony from an expert that is not a simple recounting of the expert's perceptions, however, it is likely that the testimony is available from other sources. For example, if the litigant wishes the expert to testify to professional standards or to employ his training to draw inferences from basic facts, the testimony of the particular expert is probably duplicable. So long as the testimony can be obtained from another source, the failure to compel the expert probably will not deprive the litigant of important evidence. The duty to testify is a burden upon any citizen, but the inconvenience to the witness is almost always overborne by the need of court and litigant for the witness's unique testimony. If that testimony is not unique, however, the need for the testimony is less urgent.

\section{Current Approaches}

In apparent recognition of the inherent unfairness of compelling expert testimony and the greater replaceability of much expert testimony, some courts have developed special rules concerning the compulsion of expert testimony. ${ }^{9}$ The courts have differed substan-

witnesses. See, e.g., Ex parte Dement, 53 Ala. 389, 25 Am. Rep. 611 (1875); Dixon v. People, 168 Ill. 179, 48 N.E. 108 (1897) (stating that the issue is not whether knowledge is property but whether requiring a response to a hypothetical question is a taking of property); Dills v. State, 59 Ind. 15, 19 (1877) (Biddle, C.J., dissenting); 8 Wigmore, supra note 6, at § 2203. An implicit ground for the rejection of the property argument is that acceptance of the argument would deny vast amounts of evidence to the courts since a property right would extend to any testimony-observations as well as opinions-which depended on the expert's training.

Nevertheless, both the states and the federal government respect the expert's interests in his time and training. See, e.g., FED. R. Evid. 706 (providing that a court may appoint expert witnesses only if the expert consents). See also FED. R. CRIM. P. 28; KY. R. CRIM. 9.46; N.D.R. CRIM. 28; R.I. SUPER. R. CRIM. P. 28. Consent apparently is required because a courtappointed expert may have to do out-of-court work in addition to testifying. However, the rule exhibits a concern for fairness to experts which goes beyond the constitutional mandate that the expert be compensated if he is required to perform out-of-court studies.

Some courts have suggested that a party may no more compel a particular expert to testify for him than he can compel a particular attorney to represent him. See, e.g., Cheatham Elec. Switching Device Co. v. Transit Dev. Co., 261 F. 792 (2d Cir. 1919); United States v. Howe, 26 F. Cas. 394 (W.D. Ark. 1881) (No. 15,404a). However, the expert is in theory impartial and not a hired partisan; his duty to testify is owed to the court rather than to the litigant. See 8 WIGMORE, supra note $6, \S 2192$, at $73, \S 2203(2)$ (c), at 141 .

- In addition to the approaches discussed in the text, courts and commentators occasionally have suggested applying the attorney-client privilege to experts. See State ex rel. State Highway Dep't v. 62.96247 Acres of Land, 57 Del. 40, 62-63, 193 A.2d 799, 811 (1963); City \& County of San Francisco v. Superior Ct., 37 Cal. 2d 227, 234, 231 P.2d 26, 29 (1951) (discov- 
tially in their treatment of expert witnesses. Categorization of the approaches is difficult and possibly misleading because courts usually deal only with the particular facts presented and do not announce a comprehensive "approach" to the problem. Nevertheless, four distinct methods of dealing with the problem can be isolated, each of which will be evaluated in terms of the success with which it accommodates the interests of expert and litigant without undue sacrifice of judicial economy. ${ }^{10}$

Most jurisdictions that have considered the problem have held that experts can be compelled to give professional opinions that they have formed prior to the time they are called upon to testify, ${ }^{11}$

ery); Friedenthal, Discovery and Use of an Adverse Party's Expert Information, 14 STAN. L. REv. 455 (1962); Note, Right to Compel Testimony of Expert Witness Employed by Adverse Party, 73 Dick. L. REv. 675 (1969). The attorney-client privilege would apply when the expert served as the attorney's agent to obtain information from the client. For example, in City \& County of San Francisco v. Superior Ct., 37 Cal. 2d 227, 231 P.2d 26 (1951), the court accorded the privilege to a doctor who had examined a patient solely in order to report the patient's condition to his attorney.

Bringing experts within the attorney-client privilege may shield experts from having to testify to either facts or opinions. Such a privilege could coexist with any of the other approaches used to compel expert testimony; however, the privilege would apply only to information obtained from a client and not to information independently developed by the expert. See City \& County of San Francisco, id. at 238, 231 P.2d at 29-30. Thus, the information that is most likely to be irreplaceable - that reported by the client-would be protected while information that could be duplicated by other experts could be compelled. Furthermore, the expert could not assert the privilege if his client waived it. See, e.g., State ex rel. State Highway Dep't v. 62.96247 Acres of Land, 15 Del. at 75, 193 A.2d at 817.

${ }^{10}$ Constitutional problems may exist if a criminal defendant cannot obtain expert testimony, either because the expert resists the subpoena or because the defendant cannot afford to pay the expert's fee. See People v. Watson, 36 Ill. 2d 228, 221 N.E.2d 645 (1966); Flores v. State, 491 S.W.2d 144 (Tex. Crim. App. 1973); cf. Davis v. Alaska, 415 U.S. 308 (1974) (right of confrontation includes right to expose witness's record of juvenile delinquency and present probationary status in order to show the existence of possible bias and prejudice, despite state policy of preserving confidentiality of juvenile court records); Washington v. Texas, 388 U.S. 14 (1967) (right to compulsory process cannot be limited by state's arbitrary refusal to allow co-conspirator to testify). But see Commonwealth v. Vitello, _ Mass. _ _ _ 327 N.E.2d 819, 827 (1975).

11 Courts in sixteen jurisdictions that do not compensate experts will compel experts to testify to already-formed opinions. See, e.g., Flinn v. Prairie County, 60 Ark. 204, 207, 29 S.W. 459, 459 (1895); Town of Thomaston v. Ives, 156 Conn. 166, 239 A.2d 515 (1968); Bradley v. Davidson, 47 App. D.C. 266 (1918); Dixon v. State, 12 Ga. App. 17, 76 S.E. 794 (1912); Dixon v. People, 168 Ill. 179, 48 N.E. 108 (1897); Wright v. People, 112 Ill. 540, 544 (1884); Swope v. State, 145 Kan. 928, 67 P.2d 416 (1937); Urban Renewal \& Community Dev. Agency v. Fledderman, 419 S.W.2d 741 (Ky. 1967); Barrus v. Phaneuf, 166 Mass. 123, 44 N.E. 141 (1896): Stevens v. Worcester, 196 Mass. 45, 81 N.E. 907 (1907); Johns-Mansville Prods. Corp. v. Cather, 208 Miss. 268, 44 So. $2 d 405$ (1950); State v. Bell, 212 Mo. 111, 126-27, 111 S.W. 24, 28 (1908); Main v. Sherman County, 74 Neb. 155, 103 N.W. 1038 (1905); Pengelly v. Commissioners, 8 Ohio N.P. 386, 620 (1901); Mount v. Welsh, 118 Or. 568, 585, 247 P. 815, 821 (1926); Flores v. State, 491 S.W.2d 144, 147-48 (Tex. Crim. App. 1973); Summers v. State, 5 Tex. Civ. Cas. 365, 377-78 (1879); State ex rel. Berge v. Superior Ct., 154 Wash. 144, 281 P. 335 (1929); Ealy v. Shelter Ice Cream Co., 108 W. Va. 184, 150 S.E. 539 (1929). Some courts 
but cannot be compelled to perform out-of-court work. ${ }^{2}$ The rule that experts must testify to already-formed opinions is underprotective of experts, since they can be compelled to testify regardless of whether the testimony is available from other sources. For example, a famous surgeon could be compelled to give his opinion in every malpractice case involving an operating procedure of which he disapproves. ${ }^{13}$ Also, requiring courts to determine whether an opinion is "already-formed" may impose administrative costs on the judicial system. ${ }^{14}$

In contrast, the courts of New York, New Jersey, and Pennsylvania have adopted a rule that is designed to protect the expert's investment in his training. Under the New York rule, experts cannot be compelled to give expert opinion testimony. ${ }^{15}$ This approach cre-

have hinted that even extra out-of-court work could be demanded of expert witnesses. See, e.g., Ex parte Dement, 53 Ala. 389, 397, 25 Am. Rep. 611 (1875); Logan v. Chatham County, 113 Ga. App. 491, 148 S.W.2d 471 (1966). Three jurisdictions provide by statute that experts may be compelled to testify without special compensation. See Ala. Code tit. 7, \$366 (1960); Ind. Code Ans. § 34-1-14-12 (Burns 1973); Mont. Rev. Codes ANn. § 25-414 (1967). The Indiana and Alabama statutes specify that expert opinion testimony can be compelled; the Montana statute merely states that an expert witness need not be paid more than the ordinary witness fee.

It appears from the cases that courts in the foregoing states have little or no discretion to refuse to compel experts to give opinion testimony. In Massachusetts, however, trial courts may, in their discretion, refuse to compel experts to give opinion testimony. See text and notes at notes $25-28$ infra.

12 Most cases classify opinions as already-formed or requiring out-of-court work. See, e.g., Johns-Mansville Prods. Corp. v. Cather, 208 Miss. 268, 280-81, 44 So. $2 d 405$ (1950); Ex parte Dement, 53 Ala. 389, 25 Am. Rep. 611 (1875). These cases fail to note an intermediate category: "newly-formed opinions," opinions not formed when the expert takes the stand but that would not require out-of-court work. These would in most cases be opinions formed in response to hypothetical questions that set out facts which the expert has not observed. The question of whether newly-formed opinions can be compelled has not often arisen because the subpoenaed expert in the typical case is acquainted with the facts and therefore presumably has already formed opinions from those facts. A few cases that identify themselves as following the majority approach have explicitly drawn a line between already-formed and newly-formed opinions, holding that the latter cannot be compelled. See, e.g., Kaufman v. Edelstein, 539 F.2d 811, 819 (2d Cir. 1976); State ex rel. Berge v. Superior Ct., 154 Wash. 144, 281 P. 375 (1929) (Holcomb, J., concurring). The apparent rationale for the distinction is that asking the expert to form a new opinion on the stand is more like forcing the expert to do out-of-court work for a party than it is like asking the expert to testify to what he already knows.

${ }^{13}$ Cf. Karp v. Cooley, 493 F.2d 408 (5th Cir.), cert. denied, 419 U.S. 845 (1974). In Karp, the plaintiff brought a malpractice action against Dr. Denton Cooley for implanting a mechanical heart in her husband. The plaintiff subpoenaed Dr. Michael DeBakey, the President of Baylor Medical School, knowing that DeBakey disapproved the use of such mechanical devices. Under the approach requiring experts to testify to already-formed opinions, Dr. DeBakey could be compelled to testify in every case involving the use of mechanical organs.

" This would be the case if the line between testimony which can and cannot be compelled were drawn between already-formed and newly-formed opinions; see note 12 supra.

is See, e.g., Hull v. Plume, 131 N.J.L. 511, 517, 37 A.2d 53, 56 (1944); Stanton v. Rush- 
ates more problems than it solves, however. First, it is underprotective of experts because it does not excuse their appearance at trial even though only fact testimony can be compelled. In a malpractice action alleging that an operation had been negligently performed, for example, a doctor who has no connection to the litigation could be compelled to describe how he normally performs similar operations.

Second, the approach necessitates question-by-question classification of testimony and thus can be costly to administer. The trial court frequently will encounter interruptions as the expert objects to questions on the ground that the litigant is seeking to elicit opinion testimony. The court will be required to ascertain the object of the questioning and to distinguish between expert fact and expert opinion, an often difficult task. For example, in People ex rel. Kraushaar Bros. \& Co. v. Thorpe, ${ }^{16}$ the court held that an expert who previously had appraised the property in question could be compelled to testify to his observations of the property but not to his opinions. At trial the court would have to decide whether, for instance, questions asking about the state of repair of the heating system called for fact or opinion testimony.

A third and more serious defect of this approach is that it inadequately protects the interests of the litigant who seeks to compel the testimony. Expert opinion is not necessarily duplicable, or may be duplicable only at great expense. ${ }^{17}$ Under the New York rule the litigant could be deprived of evidence altogether on an issue relevant to the litigation. The approach affords trial courts insufficient latitude to weigh the needs of litigants.

A number of states alleviate the unfairness inherent in compelling expert testimony by compensating the expert. ${ }^{18}$ In these states

more, 112 N.J.L. 115, 169 A.2d 721, 721-22 (1934); Braverman v. Braverman, 21 N.J. Super. 367, 91 A.2d 226, 227 (1952) (New Jersey cases); People ex rel. Kraushaar Bros. \& Co. v. Thorpe, 296 N.Y. 223, 225, 72 N.E.2d 165, 165-66 (1947); People ex rel. Deuel v. Shaw, 259 App. Div. 977, 977-78, 20 N.Y.S.2d 518 (1940) (New York cases); Evans v. Otis Elevator Co., 403 Pa. 13, 168 A.2d 573, 580 (1961); Pennsylvania Co. for Ins. v. City of Philadelphia, 262 Pa. 439, 105 A. 630 (1918) (Pennsylvania cases). See also Karp v. Cooley, 349 F. Supp. 827, 836 (S.D. Tex. 1972), aff'd, 493 F.2d 408 (5th Cir.), cert. denied, 419 U.S. 845 (1974).

is 296 N.Y. 223, 72 N.E.2d 165 (1947).

${ }^{17}$ For example, if the plaintiff's property in Thorpe had been destroyed or substantially altered and no other appraiser had appraised the property during the relevant time period, the appraiser's testimony would not be duplicable. See text and notes at notes $45-46$ and text at note 56 infra.

18 The following states make statutory provision for additional compensation for experts: CAL. Gov'T CODE $\$ 68092.5$ (West 1976) (additional compensation solely for opinion testimony); Colo. Rev. Stat. § 13-33-102(4) (1973); Conn. Gen. Stat. Ann. § 52-260 (West Supp. 1976) (additional compensation only for "practitioners of the healing arts, . . . dentist[s] 
experts can be compelled to give expert fact and opinion testimony in exchange for a fee in excess of the ordinary witness fee. This method has several advantages over the New York approach, the most obvious being its ease of administration. The administrative costs are simply those of determining the appropriate compensation. Difficult distinctions between fact and opinion testimony need not be drawn, and the frequent interruptions engendered by the New York approach are avoided. The compensation method also reconciles the competing interests more satisfactorily: the litigant is always assured of needed evidence, and the expert is roughly recompensed for his time and effort, although he is not, of course, paid enough to induce him to testify. The compensation approach does not truly weigh the unfairness to the expert against the litigant's need for the testimony, but it simply assumes that the litigant's need should predominate.

The New York and compensation approaches remedy one form of unfairness to experts, but do not remedy the unfairness of coercing the presence of an expert whose testimony could be substantially duplicated. Recognizing this, courts have on occasion excused the expert's appearance altogether upon a motion to quash the subpoena. ${ }^{19} \mathrm{~A}$ subpoena can be quashed in the federal system if the trial court determines that it would be unreasonable or oppressive to

or real estate appraisers"); DeL. Code tit. 10, 88906 (1975); FLA. Stat. ANn. $\$ 914.06$ (West 1973) (expert opinion testimony may be compelled in criminal cases in exchange for fee to be set by court); Iowa CODE ANN. $\$ 622.72$ (West Supp. 1977) (for expert opinions in any branch of science or for studies made in scientific and professional fields not more than $\$ 150$ per day is allowed); La. Rev. Stat. ANN. $\$ 13: 3666$ A (West 1968); ME. Rev. Stat. tit. 16, § 251 (1976 Supp.); Mich. Comp. Laws Ann. \$§ 600.2164(1), 775.13 (1968); Minn. Stat. ANN. $\$$ 357.25 (West 1966); Nev. Rev. Stat. $\S 18.010$ (2) (1973) (fees of not more than $\$ 250$ for each of three experts are taxable as costs); N.M. STAT. ANN. \& 20-1-4(B) (1975 Supp.); N.C. GeN. Stat. § 7A-314(d) (1975 Supp.); N.D. Cent. Code § 28-26-06 (1975 Supp.); Vt. Stat. AnN. tit. 32, $\$ 1554$ (1970) (expert fees allowed only in actions brought by state); VA. CoDE $\S 14.1$ 190 (1976 Supp.); Wis. Stat. ANN. \$ 814.04(2) (West 1977) (not more than \$25); Wyo. STat. $\$ 1-195$ (1975 Supp.) ( $\$ 25$ per day or such amount as the court shall allow).

Caselaw in eight of these states has established that opinion testimony can be compelled. McLenahan v. Keyes, 188 Cal. 574, 206 P. 454 (1922); Board of Comm'rs v. Lee, 3 Colo. App. 177, 32 P. 841 (1893); Town of Thomaston v. Ives, 156 Conn. 166, 239 A.2d 515 (1968); Rancourt v. Waterville Urban Renewal Auth., 223 A.2d 303 (Me. 1966); State v. Teipner, 36 Minn. 535, 32 N.W. 678 (1887); Le Mere v. McHale, 30 Minn. 410, 15 N.W. 682 (1883); State ex rel. State Highway Comm'n v. Steinkraus, 76 N.M. 617, 417 P.2d 431 (1966); Bradley v. Poole, 187 Va. 432, 47 S.E.2d 341 (1948) (but see Cooper v. Norfolk Redev. \& Housing Auth., 197 Va. 653, 90 S.E.2d 788 (1956)); Philler v. Waukesha County, 139 Wis. 211, 120 N.W. 829 (1909). The only North Carolina case in point suggests that expert opinion testimony can be compelled. In re Hayes, 200 N.C. 133, 156 S.E. 791 (1931) (dictum).

1 See, e.g., Karp v. Cooley, 349 F. Supp. 827 (S.D. Tex. 1972), aff'd, 493 F.2d 408 (5th Cir.), cert. denied, 419 U.S. 845 (1974); People v. Rhone, 267 Cal. App. 2d 652, 73 Cal. Rptr. 463 (1968); Commonwealth v. Vitello, Mass. 327 N.E.2d 819 (1975). 
enforce it. ${ }^{20}$ The standard appears to be similar or identical in the states. ${ }^{21}$ State and federal appellate courts reviewing trial court rulings on motions to quash under the abuse of discretion standard have upheld refusals to compel the appearance of experts for various reasons: because the expert had no connection with the litigation, ${ }^{22}$ because the expert lacked unique knowledge, ${ }^{23}$ or because the expert had been hired by the opposing party. ${ }^{24}$

The decision whether to quash generally lies within the trial court's discretion. In Massachusetts, however, it appears that trial courts must quash subpoenas for expert testimony under certain circumstances. In Commonwealth v. Vitello, ${ }^{25}$ the Massachusetts Supreme Judicial Court upheld a trial court's refusal to enforce a subpoena for an expert who had testified at a preliminary hearing that voiceprints were a reliable identification technique. The court recognized that the expert could have given relevant testimony about the value of voiceprints. Nevertheless, the court held that "a party may not by summons compel the involuntary testimony of an expert witness solely for the expertise he may bring to the trial, and in the absence of any personal knowledge on his part related to the issues before the judge and the jury."26 For support the court relied on its decision in Ramacorti v. Boston Redevelopment Authority, ${ }^{27}$ which held that a trial court has discretion to refuse to compel a testifying expert to state already-formed opinions. Vitello goes beyond Ramacorti in recognizing lack of personal knowledge as a per se ground for quashing a subpoena.

The Vitello decision is a salutary one in that it recognizes the importance of the non-uniqueness of the expert's knowledge. The per se rule, however, does not give sufficient weight to the litigant's need for relevant testimony. Not all expert testimony is, as a practi-

${ }^{20}$ The standard applied by the federal courts to quash subpoenas ad testificandum has been, by analogy to the standards for subpoenas duces tecum, that the subpoena be "unreasonable or oppressive." See, e.g., United States v. IBM Corp., 406 F. Supp. 175, 175 n.1 (S.D.N.Y. 1975); Broome v. Simon, 255 F. Supp. 434, 437 (W.D. La. 1966) ("[t]o protect the witness from 'annoyance, embararssment or oppression' "); FED. R. Crv. P. 45(b).

${ }^{21}$ See, e.g., People v. Rhone, 267 Cal. App. 2d 652, 73 Cal. Rptr. 463 (1968); Ryan v. Temporary State Comm'n, 33 Misc. 2d 1094, 228 N.Y.S.2d 853 (Sup. Ct.), rev'd, 16 App. Div. $2 d$ 1022, 230 N.Y.S.2d 97, aff'd, 12 N.Y.2d 708, 186 N.E.2d 121, 233 N.Y.S.2d 762 (1962); Glasper v. Westbo, 59 Wash. 2d 596, 369 P.2d 313 (1962).

22 Young v. Metropolitan Dade County, 201 So. 2d 594 (Fla. Dist. Ct. App. 1967). See Karp v. Cooley, 493 F.2d 408 (5th Cir.), cert. denied, 419 U.S. 845 (1974) (semble).

23 City and County of Honolulu v. Bonded Inv. Co., 54 Haw. 385, 507 P.2d 1084 (1973).

' 21 !d.; L'Etoile v. Director of Public Works, 89 R.I. 394, 153 A.2d 173 (1959).

23 __ Mass. __, 327 N.E.2d 819 (1975).

${ }^{28}$ Id. at $\longrightarrow, 327$ N.E.2d at 827.

${ }^{27} 341$ Mass. 377, 170 N.E.2d 323 (1960). 
cal matter, replaceable..$^{28} \mathrm{~A}$ better approach would guide and control rather than eliminate trial court discretion.

In his opinion in the case of Kaufman $v$. Edelstein, ${ }^{29}$ Judge Friendly listed considerations that should be the starting point for the development of coherent guidelines to assist trial courts in deciding whether to compel expert testimony:

Appropriate factors for consideration-some pointing against a dispensation and some for one-would be the degree to which the expert is being called because of his knowledge of facts relevant to the case rather than in order to give opinion testimony; the difference between testifying to a previously formed or expressed opinion and forming a new one; the possibility that, for other reasons, the witness is a unique expert; the extent to which the calling party is able to show the unlikelihood that any comparable witness will willingly testify; the degree to which the witness is able to show that he has been oppressed by having continually to testify; and undoubtedly, many others. ${ }^{30}$

Judge Friendly's opinion will doubtless be influential; however, the opinion simply lists the relevant considerations and does not give any guidance on how they are to be applied. The establishment of well-defined standards to guide the balancing of litigants' and experts' interests is essential to achieving fair and consistent results and administrative efficiencies.

\section{A Proposed Comprehensive Approach}

A. The Decision to Compel the Expert to Appear at Trial

Judicial economies can be effected by minimizing the time and effort invested in deciding whether an expert will be compelled to testify and what he will be compelled to testify about. The drain on judicial resources should be minimized by eliminating the questionby-question determinations required under the New York approach and instead requiring the court to make but a single determination whether to compel the testimony. That determination is most appropriately and conveniently made upon the expert's motion to quash. $^{31}$

2* See text and notes at notes $45-46$ and 56 infra.

25 539 F.2d 811 (2d Cir. 1976).

30 Id. at 822 .

"No court supervision is exercised over the issuance of subpoenas; parties may obtain subpoenas in blank from court clerks. See, e.g., FED. R. Crv. P. 45(a). An unwilling witness 
In ruling on motions to quash, the court should focus on the issue of duplicability ${ }^{32}$ Whether an expert's testimony is duplicable usually depends on the source of the expert's knowledge, and in most cases the source can be easily ascertained. Expert witnesses can be divided into three categories based on the source of the expert's relevant knowledge. The first category, "occurrence witnesses," consists of experts who have obtained their knowledge by direct observation of or participation in events of relevance to the litigation. ${ }^{33}$ The second category, "general experts," is made up of experts who have neither observed the relevant events nor specially studied the particular facts in the case. The third category, "intermediate experts" consists of experts, who, because of studies they have done, have become familiar with particular facts of the case. ${ }^{34}$ Only "occurrence expert" testimony can be presumed to be unique; the testimony of general and intermediate experts cannot. The standards governing compulsion of expert testimony should

may not wait until the time specified for his testimony to raise his objections to the subpoenas. Instead, those objections must be raised on a motion to quash. 5A MOORE's Federal Practice If 45.03[6], at 45-21 (2d ed. 1975).

In his concurring opinion in Kaufman v. Edelstein, 539 F.2d 811, 822-24 (2d Cir. 1976), Judge Gurfein noted the burden placed on an expert witness by requiring him to hire an attorney to contest the subpoena and raised the question of whether parties should be required to state what testimony would be sought from the expert prior to the issuance of a subpoena. Since even those experts who are willing to testify may be subpoenaed to assure their attendance on a specific day, cf. Bradley v. Poole, 187 Va. 432, 47 S.E.2d 341 (1948) (expert was willing to testify but refused to delay vacation even when summoned), or to entitle the expert to witness fees, e.g., Tex. Code Crim. Proc. ANN. art. 1080 (Vernon 1966), a pre-subpoena showing would radically disrupt the normal subpoena procedure and would entail large administrative expense. The consumption of judicial resources that would result outweighs the interests of the few unwilling experts who might benefit from such a presubpoena showing.

32 See text following note 7 supra. The other major difference between expert and ordi- nary witnesses that results in unfairness to experts when they are compelled to testify, their equity in the substance of their testimony, can be mitigated by provision for expert compensation. See text and notes at notes 62-65 infra.

33 Professor Graham has suggested the term "occurrence witnesses" to describe experts who were actors in or contemporaneous viewers of events forming the basis of litigation. See Graham, Discovery of Experts Under Rule 26(b)(4) of the Federal Rules of Civil Procedure: An Analytical Study (pt. 1), 1976 U. ILL. L.F. 895, 941.

${ }^{3}$ The distinction between the kind of facts known to the general expert and that kind known to the intermediate expert corresponds roughly to Professor Davis's distinction between legislative and adjudicative facts:

[F]acts are of two kinds-adjudicative and legislative. Adjudicative facts are the facts about the parties and their activities, businesses, and properties. Adjudicative facts usually answer the questions of who did what, where, when, how, why, with what motive or intent; adjudicative facts are roughly the kind of facts that go to a jury in a jury case. Legislative facts do not usually concern the immediate parties but are general facts which help the tribunal decide questions of law and policy and discretion.

K. Davis, Administrative Law Text $\$ 7.03$, at 160 (3d ed. 1972). 
depend on the type of expert testimony sought to be compelled.

1. Occurrence Experts. Occurrence experts are witnesses who directly observed conditions or events pertinent to the litigation. The occurrence expert differs from the ordinary witness in that he employed his special training in perceiving the relevant events. For example, this category would include a physician who had treated or examined an accident victim, but would not include a physician who had merely observed the accident. Because occurrence experts possess irreplaceable information, their testimony is like that of the ordinary witness, and they should be subject to the standards for compulsion applicable to ordinary witnesses. Subpoenas directed to such experts should be quashed only if it would be "unreasonable or oppressive" to compel the testimony.

Determining which experts may be classified as occurrence witnesses may be difficult when the alleged wrong occurred over an extended period of time. ${ }^{35}$ The focus of the inquiry in classifying the expert is whether it is central to the expert's value as a witness that he acquired his knowledge at a particular point in time. For example, in Kaufman $v$. Edelstein, ${ }^{36}$ an antitrust case, two computer experts had been employed by a major accounting firm to advise clients on the purchase of computer systems. The government subpoenaed the experts to testify about the recommendations they had made to customers and their opinions of the relative merits of various computer systems. ${ }^{37}$ As participants in the computer industry and observers of IBM's marketing practices, the experts should be classified as occurrence experts and thus compelled to testify in the absence of exceptional circumstances.

2. General Experts. General experts are experts unacquainted with the particular facts at issue in the litigation. An example is a physician who has never treated or examined the victim in a malpractice action who is called to testify concerning accepted medical standards. ${ }^{38}$ Because the presumption of uniqueness is not justified

${ }^{35}$ In general, the distinction will not be a difficult one to make. Moreover, the approach advocated puts a relatively small premium on correct classification of experts; even occurrence expert witnesses will be compensated if the litigants draw upon their expertness. See text following note 64 infra.

* 539 F.2d 811 (2d Cir. 1976).

${ }^{37}$ The Government proposed to ask the witnesses about their prior expressed opinions "concerning the nature and structure of the general purpose electronic digital computer systems market" from 1960 to 1972 , and also to ask them "to explain the nature of their duties as computer systems analysts, and especially to recount the advice which they gave to users and potential users." The Government disclaimed any intention of asking the witnesses for "their expert evaluation of the government's evidence." 539 F.2d at 812-13.

* See, e.g., Karp v. Cooley, 493 F.2d 408 (5th Cir.), cert. denied, 419 U.S. 845 (1974). 
in the case of a general expert, the expert should not be compelled, on his motion to quash a subpoena issued for his appearance, to demonstrate the oppressiveness or unreasonableness of the subpoena in order to avoid compulsion. When a general expert moves to quash a subpoena the motion should be granted unless the litigant can show exceptional circumstances.

In most cases, the litigant will be unable to show exceptional circumstances because it is likely that he could find another general expert willing to testify. Moreover, even if the litigant cannot obtain the oral testimony of a willing expert, other sources of the needed evidence may be available. Publications, ${ }^{38}$ judicial notice, ${ }^{40}$ prior testimony of an expert, ${ }^{41}$ or testimony of a willing expert about the opinions of an unwilling expert ${ }^{42}$ may be adequate substitutes for the testimony of the unwilling general expert..$^{43}$ The litigant should be required to demonstrate the nonduplicability of the expert's testimony because he probably will be in a better position than the expert to assess the adequacy and availability of alternatives and because he, and not the expert, stands to benefit from compulsion of the testimony. ${ }^{44}$

If a general expert's testimony is otherwise unavailable, however, the litigant has a strong claim to the testimony. Opinion testimony of a general expert may be unavailable, for example, if no other willing expert would draw the same conclusions. ${ }^{45}$ Although

39 The hearsay exception allowing the introduction of a learned treatise as a substitute for expert testimony is usually limited to established authorities in "history, medicine, or other science or art." E.g., FED. R. Evw. 803.

to Judicial notice may substitute for expert testimony, for example, where the facts noticed are not in dispute or where the issue is the preliminary determination that a scientific technique is accepted in the profession. See McCormick, supra note 7, at §§ 330-32.

" Because prior recorded testimony typically cannot be used unless the expert is unavailable, e.g., FED. R. Evid. 804(b)(1), this hearsay exception cannot be invoked to substitute for the testimony of an expert within the court's jurisdiction. It may, however, provide a good substitute for the testimony of a different unwilling expert. See text and notes at notes 47-48 infra.

${ }^{12}$ In some jurisdictions this alternative may be restricted by the requirement that the expert base his testimony only on information introduced or admissible as evidence. See, e.g., State v. David, 222 N.C. 242, 22 S.E.2d 633 (1942). To some extent all expert testimony is based on information supplied by other experts. See, e.g., Ryan v. Payne, 446 S.W.2d 273 (Ky. 1969); 2 WigMORE, supra note 7, at § 665(b).

13 Requiring a party to use alternative means of presenting the evidence may diminish its impact. For example, the subpoenaed expert may be a better witness than other experts, or using a learned treatise may be less effective than presenting a live witness. These differences will be insignificant in preliminary matters or trials to the bench. In jury trials, however, the judge will have to evaluate whether the available alternative means are reasonable substitutes for the unwilling expert in assessing the litigant's need for that expert's testimony.

" The subpoenaed expert, of course, should be free to produce another willing expert.

is For example, only one doctor may believe that marijuana is the preferred treatment for glaucoma. 
fact testimony of a general expert may be replicable in theory, in practice there may be situations in which it is reproducible only with exorbitant expenditures of time or money..$^{46}$ In order to obtain the testimony of the expert witness of his choice, the calling party should show that he has made a good-faith effort to obtain other experts at the going rate and that alternative means of introducing the evidence are not available.

If the litigant shows that no willing expert is available at a reasonable price and that the evidence cannot be obtained by means other than the oral testimony of an expert, the court must then determine whether the subpoenaed expert should testify, rather than some other unwilling expert. ${ }^{47}$ The court should compare the hardship on the subpoenaed expert to the probable hardship on other experts. In making this comparison, factors such as the number of times the expert has been compelled to testify, the expert's affiliation with the litigation or the parties, the distance the expert must travel to testify, and other commitments of the expert should be considered. The court should refuse to compel the unwilling expert to testify only if these factors indicate that it is unreasonable to do so.48

The reasonableness of according general experts such a strong presumption against testifying is demonstrated by recent cases in which courts have shown a reluctance to compel testimony of general experts. For example, in In re Estate of Rothko $0^{49}$ a New York court refused to compel an art dealer to testify about the valuation of paintings because the expert was not familiar with the particular paintings involved in the case.$^{50}$ Although the art dealer could have

16 For example, the testimony, in a pesticide poisoning case, of a scientist who had performed a long-range study of the effects of the pesticide could not reasonably be duplicated by requiring other experts to perform similar studies. This problem will arise, however, only in jurisdictions in which experts may base their opinions only on information in evidence; in other jurisdictions, a willing expert could testify based on the unwilling expert's studies even though the studies would not be admissible under the hearsay exception for learned treatises.

17 The court might conclude that the litigant may compel an expert other than the subpoenaed expert to testify. For example, the fact that a party requires favorable medical testimony does not necessarily mean that the country's foremost specialist in the field should have to testify if other, lesser known doctors would give the same testimony. See, e.g., Karp v. Cooley, 349 F. Supp. 827 (S.D. Tex. 1972), aff'd, 493 F.2d 408 (5th Cir.), cert. denied, 419 U.S. 845 (1974).

4* The "unreasonable" standard seems appropriate since a less stringent standard for compulsion would place an undue burden on the litigant who has already shown his need for the testimony and his inability to obtain willing general experts.

* 80 Misc. 2d 140, 362 N.Y.S.2d 673 (Sur. Ct. 1974).

5o The art dealer had earlier given an affidavit to the executors of the estate, describing pricing practices in the sale of paintings to dealers. The affidavit had been filed but was not in evidence. Id. at 141,362 N.Y.S.2d at 674 . 
described such practices in general, the court held that the testimony sought could not be compelled under the New York rule since it was opinion testimony, not fact testimony. ${ }^{51}$ Similarly, in the Vitello case ${ }^{52}$ the court refused to compel the testimony of a voiceprint expert who had voluntarily testified at a preliminary hearing, stating that the expert could not be compelled because he had no personal knowledge of the facts of the case. The rationales of Rothko and Vitello would appear to preclude the compulsion of general expert testimony regardless of whether the calling party could obtain the needed evidence elsewhere. In contrast, under the proposed approach to compelling general experts, a litigant would be afforded the opportunity to demonstrate that the testimony of the subpoenaed expert is effectively irreplaceable. ${ }^{53}$

3. Intermediate Experts. Whether to compel experts in the intermediate category-experts acquainted with facts peculiar to the litigation by virtue of studies they have performed ${ }^{54}$-is perhaps the most difficult problem. The testimony of intermediate experts is generally duplicable, at least in theory, because it is not testimony about immediate perceptions. The major distinction between intermediate and general experts is that the latter's testimony is usually replaceable by the litigant at lower cost. However, this distinction should not be dispositive of the initial presumption of uniqueness; the cost of replacement usually will be better known to the litigant than to the subpoenaed expert, for only the litigant

st See text and note at note 15 supra.

32 Mass. 327 N.E.2d 819, 827 (1975).

33 The executors in Rothko apparently could have shown that other experts would not have testified willingly. 80 Misc. $2 \mathrm{~d}$ at 141, 362 N.Y.S.2d at 674-75.

34 This category can be subdivided into four types: experts who acquired their knowledge of the events in issue by virtue of independent studies not connected with the case at issue; experts who performed studies on the subject for other litigation; experts informally consulted by the opposing party in this litigation; and experts specially retained by the opposing party for this litigation.

The courts have divided on the question whether a party can compel the testimony of an opposing party's expert who otherwise would not be called to testify. Cases allowing the opponent's expert to be called, although there was no indication that the party did not have other expert testimony available, include Town of Thomaston v. Ives, 156 Conn. 166, 239 A.2d 515 (1968); Urban Renewal \& Community Dev. Agency v. Fledderman, 419 S.W.2d 741 (Ky. 1967) (unclear whether expert objected); City of Buffalo v. Ives, 55 Misc. $2 d$ 730, 286 N.Y.S.2d 517 (S. Ct. 1968) (expert's report was prepared at public expense); State ex rel. State Highway Comm'n v. Steinkraus, 76 N.M. 617, 417 P.2d 431 (1966) (the report was prepared at public expense; the expert did not object to testifying); State Highway Comm'n v. Earl, 80 S.D. 139, 143 N.W.2d 88 (1966) (expert did not object). The party was not allowed to call the opponent's expert in the following cases: Boynton v. R.J. Reynolds Tobacco Co., $36 \mathrm{~F}$. Supp. 593 (D. Mass. 1941) (following state law): City and County of Honolulu v. Bonded Inv. Co., 54 Haw. 385, 507 P.2d 1084 (1973); Ramacorti v. Boston Redev. Auth., 341 Mass. 377, 170 N.E.2d 323 (1960); Evans v. Otis Elevator Co., 403 Pa. 13, 168 A.2d 573 (1961). 
knows precisely what he wants. The intermediate expert should therefore also be accorded the benefit of a presumption that his testimony is replaceable. This presumption will be more frequently overcome, however, when the subpoenaed expert comes within the intermediate category. ${ }^{55}$

The testimony of an intermediate expert may be irreplaceable because of changes in the condition of the subject matter the expert has studied or the loss of the data necessary to perform a similar study. If the litigant shows that the expert's studies cannot be reproduced the motion to quash should be denied absent, of course, a showing of oppressiveness or unreasonableness. ${ }^{56}$ On the other hand, if the subject matter of the earlier study is intact, the study could in principle be reproduced by a second expert. The presumption of duplicability would be rebutted, however, if the litigant shows that alternative sources are inadequate and that he has made a good faith effort to obtain experts but has been unsuccessful either in hiring an expert at all or obtaining one who would testify favorably. Although litigants should not be encouraged to wait to see if they can avoid obtaining their own experts, neither should they be deprived of evidence altogether.

These proposed standards for compelling intermediate experts to testify parallel those suggested for the compulsion of general expert testimony.$^{57}$ But if the litigant contends that it is unfair to require him to hire an expert to duplicate the unwilling expert's study merely because of the attendant cost and delay, no parallel to the standards proposed for general experts exists. In this case, the court should consider whether it is unreasonable to force such duplication. The court should not interpret this "unreasonableness" standard so broadly as to condemn any duplication; duplication of effort is often tolerated in an adversary system..$^{58}$ If the party has other experts who have done the requisite studies, for example, fairness to the unwilling expert should automatically overcome the litigant's desire to present cumulative testimony.

In sum, if the court is satisfied that the litigant cannot hire an expert to duplicate the studies, that any hired experts will only give

ss Other means of presenting the testimony are unlikely to be available when an intermediate expert is sought to be compelled because the testimony involves facts specific to the litigation. Learned treatises will usually not discuss such facts; few experts are likely to be informed of the facts at issue in any particular litigation; and prior recorded testimony on the same issues involved in the current litigation will rarely exist.

st See text and notes at notes 20-21 supra.

57 See text and notes at notes $45-48$ supra.

s* See, e.g., FED. R. Crv. P. 26(b)(4). 
less favorable testimony, that alternative sources are not available, or that it would be unreasonable to force him to hire a second expert to duplicate the work performed by the subpoenaed expert, it should deny the expert's motion to quash the subpoena unless the expert can show that other experts have performed similar studies. In the event other experts have specially studied the subject matter and reached similar conclusions, the court must face the issue of equity among unwilling experts. The subpoena should be quashed if the expert's special circumstances indicate that it would be unfair to compel him rather than the other expert to appear. This determination would, as in the similar situation involving general experts, turn on such factors as the number of times the expert has been compelled to testify, the distance the expert must travel to testify, and the expert's other commitments. If the subpoenaed expert had been hired or consulted by the opposing party, the court should consider whether it is fair to that party to compel his expert to appear at the behest of his opponent..$^{59}$

\section{B. The Scope of the Testimony}

A significant burden is imposed on the expert when he is compelled to appear at trial regardless of the extent to which the litigant draws upon his special learning. ${ }^{60}$ Little additional burden is imposed upon the expert witness by requiring him to testify to all relevant knowledge. Moreover, the court will be relieved of the difficult task of distinguishing among kinds of expert testimony on a question-by-question basis if the scope of the expert's testimony is not limited. Occurrence witnesses should therefore be required to testify to any knowledge gained from special studies of the matter in issue,${ }^{61}$ and both occurrence and intermediate expert witnesses

59 This consideration is analogous to the "good cause" showing required of a party under FED. R. Crv. P. 26(b)(4)(A)(ii) to obtain discovery of the opponent's expert witness. In addition, the calling party should be required to reimburse the opposing party for a portion of the costs associated with retaining that expert for the litigation. Cf. FED. R. Crv. P. 26(b)(4)(C) (requiring similar payments for discovery of an expert's information). If an expert employed or consulted by the opposing party in anticipation of litigation is compelled to testify, that employment should not be revealed to the jury since the party was under no obligation to call the expert as a witness. See, e.g., Logan v. Chatham County, $113 \mathrm{Ga}$. App. 491, 148 S.E.2d 471 (1966); Niemann v. State, 471 S.W.2d 124 (Tex. Civ. App. 1971). But see Arkansas State Highway Comm'n v. Phillips, 252 Ark. 206, 478 S.W.2d 27 (1972).

60 Not only must the expert spend time testifying, he might also feel compelled to prepare for his testimony in order not to appear ill-informed. This "vanity" problem has been noted. See, e.g., People ex rel. Kraushaar Bros. \& Co. v. Thorpe, 296 N.Y. 223, 72 N.E.2d 165, 166 (1947); Commonwealth v. Cochran, $14 \mathrm{~Pa}$. Dist. 805 (1905). This problem, however, should not affect the court's decision whether to compel expert testimony.

61 For a discussion of the analogous problem in discovery when an expert has been 
should be compelled to testify about their general knowledge of a field.

Any unfairness visited upon the expert by compelling testimony other than occurrence testimony ${ }^{62}$ can be mitigated by requiring the calling party to compensate the expert. The question of proper compensation traditionally has been intimately bound up with the question of whether the expert should be compelled to testify. Under current approaches, it is clear that an expert has no right to demand additional fees as a precondition to testifying, ${ }^{63}$ but some jurisdictions provide that courts may award additional fees as a matter of fairness. ${ }^{64}$ Under the proposed standard, an unwilling

specially retained in anticipation of litigation and is also an occurrence witness, see Comment, Discovery of Expert Information Under the Federal Rules, 10 U. Rrch. L. Rev. 706 (1976).

2 This unfairness to experts is particularly acute when an expert who has gained most of his knowledge by study also possesses some occurrence evidence. For example, an econo. mist who has studied price-fixing in an industry normally would not be compelled to testify because he is an intermediate witness. If, however, some of the documents which he has seen are later missing, a party may wish to call him to establish the previous existence of these documents. Even if the expert has not relied on these documents in forming his opinions, so that his testimony is replaceable, he would be an occurrence witness as to the existence of the documents. If the expert could be compelled to testify to the existence of the documents, he could, under the proposed system, be compelled to give his opinions from his study as well. The expert's only argument against being required to testify to his expert opinion would be a claim that his testimony regarding the existence of the documents was not expert testimony, and that since he had not been compelled to testify as an expert, he should not have to give any expert testimony. The litigant could contend, however, that the expert's knowledge of the character of the missing documents depended on his expert training, so that all of the testimony was expert testimony.

The proposed system, with its unlimited scope of testimony, may encourage parties to contend that intermediate experts are, in fact, occurrence witnesses. It will be difficult to resist this inference if the expert has had contact with witnesses other than the client (communications with the client may be protected under the attorney-client privilege, see note 9 supra). But see text and notes at notes 71-74 infra.

c The few cases that have held otherwise have either been overturned or have been ignored. See note 8 supra; 8 WIGMORE, supra note 6 , at $\$ 2203$, at 137-38.

4 See note 18 supra. In order to avoid administrative difficulties, all states that award expert fees compensate for the time spent testifying, rather than for the time spent testifying to expert knowledge. Most states leave the computation of the amount of the fee to the judge's discretion.

Four approaches are used by different jurisdictions to determine which experts should be compensated. The first, compensating certain experts (usually physicians) for their testimony regardless of its content, relates more to the self-interest of certain experts than to any conception of fairness to all litigants and experts. See, e.g., Conn. GEN. STat. ANN. \& 52-260 (West Supp. 1976) (additional compensation only for a "practitioner of the healing arts, dentistry, and real estate appraisal"). The most common approach is to pay experts who give any testimony that uses their expert skill or knowledge. This system is a compromise between the goal of compensating for the use of an expert's special skills and the goal of judicial economy. A third approach, compensating the expert only if he has given an expert opinion, appears at first blush to be the most just. See, e.g., Colo. REv. STAT. § 13-33-102 (1974); Iowa Code AnN. $\$ 622.72$ (West 1950); La. Rev. Stat. AnN. $\$ 13: 3666$ A (West 1967); Mich. Comp. 
witness would be compensated by the calling party whenever the court and litigant take advantage of the expert's investment in his training.

Ideally, the system should compensate the expert only when, and to the extent that, it draws upon his special training. But it would be anomalous if a system designed in part to relieve courts of the burden of drawing distinctions between kinds of expert testimony for purposes of compulsion were to require courts to draw those same distinctions for compensation purposes. For reasons of administrative ease, any expert whose appearance is compelled should receive his reasonable fees for time spent testifying if he gives any testimony employing his expert skill or training. ${ }^{65}$

\section{Relationship of the Proposed System to the Federal Discovery RULES}

Rule 26(b)(4)(B) of the Federal Rules of Civil Procedure allows discovery of experts retained or specially employed by the opposing party, but who will not be called as witnesses by that party, only upon a showing of exceptional circumstances. ${ }^{66}$ This limitation prevents the unfairness that would result if a party were permitted to benefit freely from his opponent's trial preparation. ${ }^{67}$ The rule fur-

LAws ANN. $\$ 600.2164$ (1968). Unfortunately, this approach is not a practical one, because the wording of a question may determine whether the response sounds like "fact" or "opinion" and because the courts must decide whether previously-formed or only newlyformed opinions can qualify for the expert fee. See, e.g., Landry v. Stadium, 256 So. $2 d 343$ (La. Ct. of App. 1971). A fourth approach, paying expert fees only to experts who give opinion but not fact testimony (presumably this is meant to include those whom this comment has defined as general experts, see Bureau of Medical Economics v. Cossette, 44 Cal. App. 3d supp. I, 118 Cal. Rptr. 242 (1974)), is attractive because it compensates those experts who are least like ordinary witnesses. Once the court has determined that it is fair to compel an expert to testify, however, there is no reason to favor general experts over other experts who may also be required to give opinions.

${ }^{\text {os }}$ If the court need not distinguish between types of expert testimony, computation of an expert's "reasonable fees" should not be difficult. The expert can be paid his usual fees for the period of time spent testifying. See, e.g., Bureau of Medical Economics v. Cossette, 44 Cal. App. 3d supp. I, 118 Cal. Rptr. 242 (1974); Green v. Jefferson Truck Service, Inc., 274 So. 2d 396, 399 (La. Ct. of App. 1973).

${ }^{66}$ See Fed. R. Crv. P. 26(b)(4)(B) and Fed. R. Crv. P. 35 (relating to court-ordered examinations). But see Graham, Discovery of Experts Under Rule 26(b)(4) of the Federal Rules of Civil Procedure: An Empirical Study and a Proposal (pt. 2), 1977 U. ILL. L.F. 169, 193. Professor Graham's survey found that discovery of opponent's experts not expected to be called as witnesses takes place in a large percentage of cases. Experts who will be called as witnesses by the opposing party may be discovered on a lesser showing. FED. R. Crv. P. $26(\mathrm{~b})(4)(\mathrm{A})$.

${ }^{67}$ Any unfairness to the expert is mitigated by payment for the time spent testifying. See FED. R. Crv. P. 26(b)(4)(C). The Advisory Committee Notes on discovery provide, however, that "a party may not obtain discovery simply by offering to pay fees and expenses." 48 F.R.D. 487,505 (1970). 
ther prohibits discovery of experts informally consulted by a party ${ }^{88}$ and allows unfettered discovery of experts who were occurrence witnesses. ${ }^{69}$ The rules, however, do not address the question of whether general experts and certain intermediate experts are subject to discovery..$^{70}$

Competing policies must be considered in determining the degree to which these experts should be subject to discovery. Parties should be entitled to discover all information "reasonably calculated to lead to the discovery of admissible evidence," ${ }^{11}$ as well as all information directly relevant to the pending action. Yet experts who would not be compelled to testify at trial should also be protected from free discovery. The deposition of an expert who does not appear at trial might be admissible as evidence under a hearsay exception. ${ }^{72}$ Thus the litigant, under certain circumstances, may be able to obtain the benefit of the expert's special skills free of charge. More important, if litigants could obtain expert testimony by the strategem of deposing experts who are not amenable to trial subpoenas, the goal of mitigating the unfairness in compelling expert testimony would be frustrated.

The court therefore should utilize the procedure that is applica-

a "Subdivision (b)(4)(B) is concerned only with experts retained or specially consulted in relation to trial preparation. Thus the subdivision precludes discovery against experts who were informally consulted in preparation for trial, but not retained or specially employed." Advisory Committee Notes, Proposed Amendments to the Federil Rules of Civil Procedure Relating to Discovery, 48 F.R.D. 487, 504 (1970).

s The Advisory Committee stated that "the subdivision does not address itself to the expert whose information was not acquired in preparation for trial but rather because he was an actor or viewer with respect to transactions or occurrences that are part of the subject matter of the lawsuit. Such an expert should be treated as an ordinary witness." 48 F.R.D. at 503. See also Comment, Discovery of Expert Information Under the Federal Rules, $10 \mathrm{U}$. Rich. L. REv. 706, 718 (1976) (discussing the problem of depositions of experts who were actors or viewers and also retained or specially employed by a party in anticipation of the litigation).

" Experts not covered by rule 26(b)(4) include general experts and intermediate experts who obtained their knowledge of the matters at issue from independent study. Professor Graham suggests that discovery of "pure" experts should be permitted, but conditioned on payment of the expert's reasonable fees. Presumably general experts and intermediate experts not covered by rule 26(b)(4) are included in this category. Graham, Discovery of Experts under Rule 26(b)(4) of the Federal Rules of Civil Procedure: An Analytical Study (pt. 1), 1976 U. ILL. L.F. 895, 934-43. Graham also concludes that even discovery of informally consulted experts should be permitted under exceptional circumstances. Id. at 940 .

"FED. R. Crv. P. 26(b)(1).

72 A litigant might depose an expert who would not be subject to subpoena for trial under the standards set out above. Since the expert would thus be "unavailable," as is usually required for the hearsay exception, that deposition could be used in lieu of the expert's live testimony. Although in some respects the burden is greater on one who must appear at trial than on an expert who will only be deposed because, for example, the expert can set the time and place of the deposition, there is no justification for allowing a litigant to take advantage of the expert's skill even under this less burdensome format. 
ble to trial subpoenas when an unwilling general or intermediate expert moves either for a protective order ${ }^{73}$ or to quash a deposition subpoena. The burden should be upon the litigant to show his need for the testimony. If the party makes an adequate showing, the court should deny the expert's motion unless he demonstrates that it is unreasonable to compel him rather than some other unwilling expert. This method will differ in two respects from that applied when an expert is subpoenaed for trial. First, the litigant need only demonstrate the probable uniqueness of the testimony. Since discovery occurs early in the litigation, it is unreasonable to require parties at that stage to establish conclusively the irreplaceability of the testimony sought. The second variation follows from the first. In order to prevent abuse of the relaxed standard for permitting deposition of experts, the scope of the deposition should be limited, in certain cases, to determining whether the expert in fact possesses irreplaceable knowledge relevant to the litigation. This limitation will be necessary only in cases in which the litigant claims that the expert is an occurrence witness and the expert claims he is not. If the limitation were not imposed, a litigant could claim that an expert was an occurrence witness and depose the expert. Even if it became apparent at the deposition that the expert was not an occurrence expert, the litigant could continue deposing the expert concerning his opinions and then introduce the deposition at trial, thus avoiding the limitations placed on subpoenas for trial. If the parties agree on the category in which the expert belongs, however, the only problem to be resolved is whether the expert should be deposed at all.

Under this system both general and intermediate experts could be deposed whenever their testimony could also be compelled at trial. ${ }^{74}$ In addition, intermediate experts could be deposed whenever there is a conflict between the litigant and the expert over whether the expert possesses irreplaceable information. In that event, discovery would be limited to establishing whether or not the expert's testimony is replaceable. If discovery reveals that the expert's testimony is theoretically replicable, further discovery should be permit-

${ }^{73}$ An expert may seek a protective order denying or limiting discovery. FED. R. Crv. P. 26(c), 30(d).

74 See text and notes at notes 38-53 supra (general experts); text and notes at notes 5459 supra (intermediate experts). This severe restriction on the possibility of discovering general experts should not unduly hamper discovery, since the information that could be discovered from a general expert would usually be available from other sources, such as other experts or publications. Since a party may depose even a general expert if he can show that the testimony is not available from other sources, the system would give access to all information of general experts likely to lead to admissible evidence. 
ted only if the standards for compelling the trial appearance of intermediate experts with replicable knowledge are satisfied..$^{75}$ If the expert can be compelled to testify at trial, full discovery should be allowed. Since the requirements for deposing an unwilling expert are substantially identical to those for compelling testimony at trial, courts will normally have to make only one decision on whether to compel an expert to testify.

\section{ConcLusion}

This comment has suggested that it is unfair to compel experts to testify in all cases because expert testimony differs in kind from ordinary testimony. Current approaches to defining the circumstances in which experts can be compelled to testify are often underprotective of litigants or experts and wasteful of judicial resources. The comment has attempted to balance the interests involved. It has proposed a comprehensive approach to the problem that distinguishes among experts on the basis of the source of the expert's knowledge and focuses on the question of whether the testimony is in fact replaceable. ${ }^{76}$

The proposed approach varies the burden of proof depending on the expert's relationship to the matters being litigated. Experts who were not occurrence witnesses are accorded the benefit of a presumption that their testimony is irrepleacable. A party can overcome this presumption by showing that the testimony is unavailable from other sources; if this presumption is overcome, the court should consider whether it is unreasonable to compel the particular expert to testify instead of other unwilling experts. Because of the nature of the testimony sought it is anticipated that parties will have more difficulty overcoming the presumption for "general" than for "intermediate" experts. Once the court has determined that an expert may be compelled to appear, no additional distinctions between kinds of expert testimony need be made; any unfairness to the expert in compelling this testimony can be mitigated by requiring the litigant to pay the expert's reasonable fees.

Similar considerations apply in compelling discovery of experts. If a party contends that an expert's information is irreplaceable but the expert contends that it is not, discovery should be lim-

${ }^{75}$ See text and note at note 58 supra.

7 This comprehensive approach could be implemented either by interpreting the "unreasonable or oppressive" standard for quashing subpoenas, see text and notes at notes 20-21 supra, to encompass the suggested standards or by amending rules governing subpoenas, e.g., FED. R. Crv. P. 45, or rules governing discovery of experts. E.g., FED. R. Crv. P. 26(b)(4). 
ited to establishing such irreplaceability. Only if the party can show that the expert can be compelled to testify should full discovery be permitted.

Most courts have treated alike experts who were occurrence witnesses and general and intermediate experts. By using presumptions protective of the latter two types of experts, presumptions that can be overcome by an adequate demonstration of the need for the expert's testimony, courts can achieve the goal of obtaining all relevant testimony without unfairly burdening experts or unduly sacrificing judicial economy.

Marjorie Press Lindblom 